\title{
腎機能の生理学的発達を考慮した 腎排泄型薬刘における小児薬用量の近似推定法
}

\author{
鈴木信也 ${ }^{* 12}$, 村山悠佳 ${ }^{1}$, 杉山恵理花 ${ }^{1}$, 関山正夫 ${ }^{2}$, 佐藤 均 $^{1}$ \\ 昭和大学薬学部薬物動態学教室 ${ }^{1}$, 神奈川県警友会けいゆう病院薬局 ${ }^{2}$
}

\section{Approximation Method for Estimating Pediatric Doses of Renal-Excretion Drugs Based on Physiological Development of Renal Function}

\author{
Shinya Suzuki ${ }^{* 12}$, Yuka Murayama1, Erika Sugiyama ${ }^{1}$, \\ Masao Sekiyama ${ }^{2}$ and Hitoshi Sato ${ }^{1}$ \\ Department of Clinical and Molecular Pharmacokinetics/Pharmacodynamics, \\ School of Pharmaceutical Sciences, Showa University ${ }^{1}$ \\ Department of Pharmacy, Kanagawa Prefectural Keiyukai Keiyu Hospital ${ }^{2}$
}

$\left[\begin{array}{l}\text { Received A pril 15, } 2009 \\ \text { A ccepted A ugust 17, } 2009\end{array}\right]$

\begin{abstract}
We investigated the pediatric doses of drugs for children aged 2 years to less than 15 years for the following age groups: early childhood (2-5 years), childhood (6-11 years), and puberty (12-14 years). Pediatric dosages indicated in package inserts of renally excreted drugs (vancomycin, fosfomycin, arbekacin, norfloxacin, amoxicillin, and digoxin) were adjusted us ing three variables: body, body surface area (BSA), and glomerular filtration rate (GFR). It was found that Dose/GFR was a better factor for adjustment than Dose/Body and Dose/BSA because Dose/GFR showed little variation with age during childhood. Based on the ratio between childhood and adult GFR $\left(G_{F R} / G F R_{A}\right)$, we established a formula for calculating the pediatric dose $\left(D_{C}=D_{A} \cdot G F R_{C} / G F R_{A}\right)$ and derived linear approximation and second-order approximation equations stratified by gender for clinical application. Compared with the Augsberger equation, these approximation methods produced smaller variations from the dosages indicated in the package inserts for almost all the drugs examined and enhanced predictability. While the linear and second-order approximation equations produced similar results, the former was considered to be more useful in the clinical setting due to its simplicity. The linear equations proposed for males and females in this study are $D_{\mathrm{c}} \cong D_{\mathrm{A}} \cdot(0.054 \mathrm{Age}+0.093)$ and $\mathrm{D}_{\mathrm{c}} \cong \mathrm{D}_{\mathrm{A}} \cdot(0.062 \mathrm{Age}+0.12)$, respectively.

Our new method of estimating pediatric doses may be better than conventional methods (A ugsberger, Y oung, Clark, and Crawford equations, and von Harnack conversion table) because of its compatibility with pharmacokinetic mechanism(s). Conventional methods do not consider drug metabolism/excretion pathways and their physiological variations.
\end{abstract}

Key words — pediatric dose, dose estimation, glomerular filtration rate, early childhood, childhood, puberty

\author{
緒言 \\ 小児においては薬物動態と薬力学が十分に検討されて \\ いないため，小児に対し用量・用法が未承認である医薬 \\ 品が多く，薬用量を設定することが困難な場合がある． \\ 実際に，医療現場における質疑応答および疑義照会デー \\ タベース ${ }^{11}$ 上においても，小児薬用量についての質疑応 \\ 答およひ疑義照会事例は多く，小児薬物療法の適正使用 \\ か望まれている。 \\ 添付文書小児薬用量は多くの場合体重あたりで表現さ
}

れる.しかし，弚の絶対值は成人量とは異なるため，小 児薬用量経験のない新薬においては設定が容易ではな い. 弚のため，医師が小児薬用量の記載がない用量・用 法の医薬品を処方する際に，年齢，体重，体表面積から 成人薬用量に基づいて小児薬用量を推定する方法 (A ugsberger 式，Y oung 式，Clark 式，Crawford 式，von Harnack の換算表)が一般的に用いられている．しかしな がら，生理学的発達を直接考慮した薬用量推定式はな い.すでにわれわれは腎排泄型薬物において薬物クリア ランス(clearance : CL) と直接的に関係する血漿蛋白非結 合型分率(fp), 系球体乃過速度(glomerular filtration rate: 
GFR)および尿細管分泌クリアランス(tubular secretion clearance : Sc)を用いて，成長過程に応じた新生児・乳 幼児(2歳以下)薬用量の推定を行い, 従来の推定式より も良好な結果を得たことを報告している2).

そこで本研究では, 2 歳以上 15 歳未満の小児期(幼児 期，学童期，思春期)を対象年齢とし，小児薬用量の推 定を試みた．まず，主として腎排泄型薬物の添付文書小 児薬用量を個体(Body)あたり，標準体表面積(body surface area : BSA)あたりおよびGFR あたりの值として表 現することで, 成長に応じた薬用量変化に最も相関する 小児期における変動因子を検討した．また，腎排泄型薬 物について, 臨床現場で汎用性の高い近似式を算出し, 弚の妥当性について添付文書小児薬用量を基準として従 来より汎用されているBSA を線形近似した A ugsberger 式と比較し検討したので報告する．

\section{方法}

\section{1. 小児薬用量の変動因子の検討}

検討に用いた薬物は，添付文書に小児薬用量の記載が あり, 尿中未変化体排泄率が $75 \%$ 以上の腎排泄型薬剂 であるバンコマイシン $(\mathrm{VCM})^{3)}$,ホスホマイシン $(\mathrm{FOM})^{4-6)}$ アルベカシン $(\mathrm{ABK})^{7.8)}$, ノルフロキサシン $(\mathrm{NFLX})^{9.10)}$, アモキシシリン $(A M P C)^{11,12)}$, ジゴキシン $(D G X)^{13,14)}$ とし た(Table 1). 光して, 各薬剂の添付文書小児薬用量 (Dose/day)を用いて，男女別にBody，BSA，GFRあた りで光れ攵れ薬用量を表現し，Dose/Body(mg/body)， Dose $/ B S A\left(\mathrm{mg} / \mathrm{m}^{2}\right)$, Dose $/ \mathrm{GFR}(\mathrm{mg} \cdot \mathrm{min} / \mathrm{mL})$ の值を各年 齢ごとに算出した.BSA は厚生労働省平成 12 年度乳幼 児身体発育調査報告書(http: //www.mhlw.go.jp/houdou/ 0110/h 1024-4.html)および文部科学省平成 12 年度学校 保健統計調査報告書(http : / / www.mext.go.jp/b_menu/ toukei/001/index 03.htm)の標準身長(HT)，標準体重(Wt) から Dubois式(Eq. (1))を用いて算出した .さらに，GFR $(\mathrm{mL} / \mathrm{min})$ は，既報の式(Eq. (2) $)^{15)}$ を用いて BSA より算出 した .

$B S A\left(m^{2}\right)=71.84 \times H T(\mathrm{~cm})^{0.725} \times W t(k g)^{0.425} \times 0.0001$

$G F R(\mathrm{~mL} / \mathrm{min})=\left(-6.1604 \times B S A^{2}\right)+(99.054 \times B S A)-$ 17.74

-..Eq. (2)

例えば，2歳および10歳男児の場合, BSA $\left(m^{2}\right)$ は $0.5122,1.124, \mathrm{GFR}(\mathrm{mL} / \mathrm{min})$ は 31.38，85.78となり，対 象薬剂が VCM の場合, Dose/Body(mg/body)は 464.0, 1328.0 , Dose/BSA (mg/m²)は 905.9, 1181.5 , Dose/GFR $(\mathrm{mg} \cdot \mathrm{min} / \mathrm{mL})$ は $14.79,15.48$ となる .

また，最小および最大薬用量がともに添付文書に記載 されている場合は, 最小薬用量を用いて検討を行った . 最大薬用量は, 効果以外にも最大耐用量の観点から決め られていることが多いため，検討対象としなかった．光 して, 小児の発達段階を幼児期(early childhood)(2〜 5 歳), 学童期(childhood)(6〜11歳), 思春期(puberty)(12〜 14 歳)に層別化した . 各年齡群の小児期全体の平均值か らのバラツキを後述の方法で評価し，小児の発達に伴う 変化に最も相関する変動因子を検討した．

\section{2. 小坚薬用量推定式の導出}

バイオアベイラビリティ $(F)$, 全身クリアランス(clearance : $\mathrm{CL})(\mathrm{L} / \mathrm{hr} /$ body $)$, 定常状態における平均血中濃度 $(\overline{C s s})$ ，投与間隔 $(\mathrm{T})$ を用いると，維持投与量(dose：D) は，Eq. (3)のように表される．Fが成人と小照で同等で あると仮定すると(静脈内投与時 : $\mathrm{F}=1)$, 同一の $\overline{C s s}$ を

Table 1 . Doses for Children and Adults Described in Package Inserts, Urinary Excretion Ratio of the Unchanged Drug

\begin{tabular}{|c|c|c|c|}
\hline & Doses for children ${ }^{a}$ & Doses for adults ${ }^{\mathrm{a}}$ & Urinary excretion ratio of the unchanged drug \\
\hline $\mathrm{VCM}$ & $40 \mathrm{mg} / \mathrm{kg} / \mathrm{day}^{3)} \mathrm{iv}$ & $2000 \mathrm{mg} / \mathrm{day}^{3)} \mathrm{iv}$. & $85 \sim 90 \%^{31}$ \\
\hline FOM & $\begin{array}{l}40 \sim 120 \mathrm{mg} / \mathrm{kg} / \mathrm{day}^{4)} \text { p.o. } \\
100 \sim 200 \mathrm{mg} / \mathrm{kg} / \mathrm{day}^{5} \mathrm{iv} .\end{array}$ & $\begin{array}{l}2000 \sim 3000 \mathrm{mg} / \mathrm{day}^{4)} \text { p.o. } \\
2000 \sim 4000 \mathrm{mg} / \text { day }^{5)} \text { iv. }\end{array}$ & $85.5 \%{ }^{6}$ \\
\hline ABK & $4 \sim 6 \mathrm{mg} / \mathrm{kg} / \mathrm{day}^{7)} \mathrm{im} . \mathrm{iv}$. & $150 \sim 200 \mathrm{mg} / \mathrm{kg} / \mathrm{day}^{7)} \mathrm{im}$. iv. & $86.75 \%$ \\
\hline NFLX & $6 \sim 12 \mathrm{mg} / \mathrm{kg} / \mathrm{day}^{9)}$ p.o. & $300 \sim 800 \mathrm{mg} / \mathrm{day}^{10)}$ p.o. & $78.4 \%{ }^{9)}$ \\
\hline $\mathrm{AMPC}$ & $20 \sim 40 \mathrm{mg} / \mathrm{kg} /$ day $^{11)}$ p.o. & $750 \sim 1000 \mathrm{mg} /$ day $^{11)}$ p.o. & $86 \%^{12)}$ \\
\hline DGX & $\begin{array}{c}\text { (maintenance dose) } \\
0.008 \sim 0.020 \mathrm{mg} / \mathrm{kg} / \text { day }^{13)} \text { p.o. }\end{array}$ & $\begin{array}{c}\text { (maintenance dose) } \\
0.25 \sim 0.50 \mathrm{mg}^{- \text {day }^{13)}} \text { p.o. }\end{array}$ & $76 \%{ }^{14)}$ \\
\hline
\end{tabular}

The bold and italic numbers are the values employed for the prediction of doses. 
得ることができる投与量比は Eq. (4)により与えられる (C：小児, $A$ ：成人).

$$
\begin{array}{ll}
D=\frac{C L \cdot \overline{C s s} \cdot \mathrm{T}}{F} & \cdots \text { Eq. (3) } \\
\frac{D_{C}}{D_{A}}=\frac{C L_{C} \cdot F_{A}}{C L_{A} \cdot F_{C}}=\frac{C L_{C}}{C L_{A}} & \cdots \text { Eq. (4) }
\end{array}
$$

腎クリアランス(renal clearance: CLr)は , GFR , fp ,Sc， 尿細管再吸収率 $(R)$ を用いると，Eq. (5)のように表され

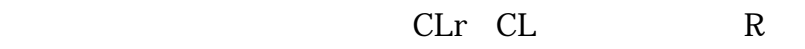
成人と小児で同等であると仮定すると，Eq. (4)は Eq. (6) と表される .

$$
\begin{aligned}
& C L r=(f p \cdot G F R+S c) \cdot(1-R) \\
& \frac{D_{C}}{D_{A}}=\frac{C L_{C}}{C L_{A}}=\frac{C L r_{C}}{C L r_{A}} \cong \frac{f p_{C} \cdot G F R_{C}+S c_{C}}{f p_{A} \cdot G F R_{A}+S c_{A}}
\end{aligned}
$$

尿細管からの分泌量は，尿細管の容積ではなく，尿細 管上皮細胞の膜表面積に影響を受けるのではないかと考 え, 膜面積の小児と成人の比を体表面積の小児と成人の 比で近似できると仮定すると，Scの小児と成人の比は Eq. (7)と表される .

$$
\frac{S c_{C}}{S c_{A}} \cong \frac{B S A_{C}}{B S A_{A}}
$$

また , Eq. (2)に示すように GFR はBSA の 2 次関数で あるため，GFR の小児と成人の比を BSA の小児と成人 の比で近似できると仮定すると，GFRの小児と成人の 比は Eq. (8)と表される .

$$
\frac{G F R_{C}}{G F R_{A}} \cong \frac{B S A_{C}}{B S A_{A}}
$$

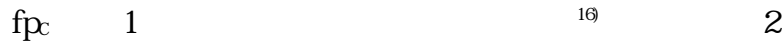
歳以上の小児(幼児以上)では $\mathrm{fp}_{\mathrm{c}} \cong \mathrm{fp}_{\mathrm{A}}$ と近似できる．光 こでEq. (6)は , Eqs. (7)(8)より Eq. (9)となる .

$$
\begin{aligned}
D_{C} \cong D_{A} \cdot \frac{f p_{C} \cdot B S A_{C}+S c_{A} \cdot \frac{B S A_{C}}{B S A_{A}}}{f p_{A} \cdot B S A_{A}+S c_{A}} & = \\
D_{A} \cdot \frac{B S A_{C} \times\left(\frac{f p_{C} \cdot B S A_{A}+S c_{A}}{B S A_{A}}\right)}{f p_{A} \cdot B S A_{A}+S c_{A}} & =D_{A} \cdot \frac{B S A_{C}}{B S A_{A}}
\end{aligned}
$$

一方，Eq. (6)は，Eqs. (7)(8)より $\mathrm{Sc}_{\mathrm{C}} / \mathrm{Sc}_{\mathrm{A}} \cong \mathrm{GFR}_{\mathrm{C}} / \mathrm{GFR}_{\mathrm{A}}$ の関係も成り立つため Eq. (10)と表せる .

$$
\begin{aligned}
D_{C} \cong D_{A} \cdot \frac{f p_{C} \cdot G F R_{C}+S C_{A} \cdot \frac{G F R_{C}}{G F R_{A}}}{f p_{A} \cdot G F R_{A}+S C_{A}}= \\
D_{A} \cdot \frac{G F R_{C} \times\left(\frac{f p_{C} \cdot G F R_{A}+S c_{A}}{G F R_{A}}\right)}{f p_{A} \cdot G F R_{A}+S c_{A}}=D_{A} \cdot \frac{G F R_{C}}{G F R_{A}}
\end{aligned}
$$

つまり，小児薬用量はBSA の小児と成人の比，または GFR の小児と成人の比として近似できる二つの可能性 が示される .前項の小児薬用量変動因子の解析において， より適切な式を次項の近似式導出に用いることとした .
3. 小児薬用量推定近似式の導出

年齢ごとの平均身長と平均体重をデータベースから抽 出することは臨床の場では困難であるため，年齢のみを 用いる近似式による推定のほうがより有用性が高いと考 え, 小児薬用量推定式の線形および二次の近似式を導出 した。

小児薬用量推定近似式は, 従属変数 y $D_{C} / D_{A}$, 独立 変数 $\mathrm{x}$ をAge とし, $D_{c}$ の変動に合わせ, 係数 $a, b, c$, d, e を用いると Eqs. (11)(12)と表せる .

$$
\begin{array}{ll}
\text { 線形近似: } D_{C} / D_{A}=a \cdot A g e+b & \cdots \text { Eq. (11) } \\
\text { 二次近似: } D_{C} / D_{A}=c \cdot A g e^{2}+d \cdot A g e+e & \cdots \text { Eq. (12) }
\end{array}
$$

そして，年齡と $D_{c} / D_{A}$ (男・女各 $D_{c} / D_{A}$ の年齢による 変化曲線)の図を用いて光れ攵れ近似することで最適な 係数を算出した(Microsoft Excel $\left.{ }^{\circledR}\right)$. なお， Dc は，2〜15 歳を 156 点に等分割した年齢(約 0.083 歳ごと)における 身長・体重を用いEqs. (1)(2)より算出した . 同樣に $D_{A}$ は, 成人の標準身長・体重を用いて Eqs. (1)(2)より算出 した。

\section{4. 評価方法および統計処理}

\section{1)小児薬用量変動因子の検討}

検討薬剂の薬用量を補正した值(Dose/Body，Dose/ BSA，Dose/GFR)ごとに，小児期全体の平均值に対する 男女別の各年齢群(幼児期，学童期および思春期)の平均 值のバラツキを評価するため，男女別および年齢群別の root mean squared prediction error (RMSE) $)^{17)}$ を以下の Eq. (13)にて算出した .

$$
\text { 相対 } \operatorname{RMSE}(\%)=\sqrt{\frac{1}{n} \sum_{i=1}^{n}\left(\frac{Z_{i}-\bar{Z}_{i}}{\bar{Z}_{i}}\right)^{2}} \times 100 \quad \cdots \text { Eq. (13) }
$$

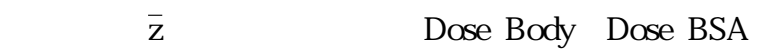
Dose/GFR の平均値， $\mathrm{z}$ は，男女ごとの各年齢群を 48等 分割して算出したDose/Body, Dose/BSA, Dose/GFR の平均値とした $(n=48)$.

さらに算出された Dose/BSA ,Dose/GFR の相対 RMSE \%值についてWilcoxon t-testを用いて検定を行い, $\mathrm{p}<$ 0.05 を有意差ありとした(SPSS ${ }^{\circledR} 11.0 \mathrm{~J}$ for Windows, SPSS Inc.)

2)小児薬用量推定近似式の妥当性の検討

小児薬用量推定近似式の妥当性(予測精度)を検討する ために，添付文書小児薬用量を基準として，線形および 二次近似式を用いて算出される小児薬用量, BSA を線 形近似した A ugsberger 式(Eq. (14))を用いて算出される 小児薬用量との間の相対 RMSE \%(Eq. (13))を算出した。 ただし，Eq. (13)において，zには各推定法による各薬 剂の小児薬用量推定值を用い, $\bar{z}$ には各薬剂の添付文書 小児薬用量とし，2歳から 1 歳おきの年齢 $(n=13)$ ごとに z, z を算出した . 
医療薬学 Jpn. J. Pharm. Health Care Sci.

A ugsberger 式: $D_{C}=D_{A} \times \frac{(\text { Age } \times 4+20)}{100} \quad \cdots$ Eq. (14)

なお，算出された小児薬用量が成人量を超える場合に は成人量を用いた . 各相対 RMSE％値の有意差について はWilcoxon t-test を用いて検定を行い $p<0.05$ を有意差 ありとした(SPSS ${ }^{\circledR} 11.0 \mathrm{~J}$ for Windows, SPSS Inc.) .

さらに, 検討薬阂の添付文書小児薬用量と線形近似

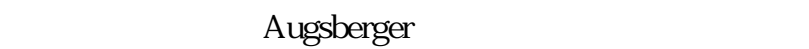
小児薬用量について, 小児薬用量/成人薬用量比 $\left(\mathrm{D}_{\mathrm{c}} /\right.$ $\mathrm{D}_{\mathrm{A}}$; pediatric/adult dose ratio)をとり，相関解析を行っ た(Microsoft Excel $\left.{ }^{\circledR}\right)$. 光して，相関式の傾きがより1に 近く,y切片がより0に近い推定式を添付文書小览薬用 量の推定式として精度が高いと判断した。

\section{結果}

\section{1. 小児薬用量の変動要因の検討}

小児期全体の平均值に対する男女別の各年齢群(幼児 期，学童期および思春期)の平均值の相対 RMSE％を， 検討薬剂ごとに各補正值(Dose/Body，Dose/BSA，Dose/ GFR)間で比較した(Fig. 1)，VCM(iv.)，FOM(p.o.)，ABK (iv.)，NFLX (p.o.)における小児期全体の平均值に対する 男女別の各年齢群のバラツキは,Dose/GFR が Dose/BSA と比較して有意に小さかった( $p<0.05)$. AMPC(p.o.), DGX(p.o.)におけるバラツキには, Dose/GFR と Dose/ BSA との間に有意差はなかった( $p>0.05)$. 一方で, FOM(iv.)におけるバラツキは, Dose/GFR がDose/BSA と比較して有意に大きかった $(p<0.05)$.

\section{2. 小児薬用量推定近似式の導出}

上記の結果より，小児薬用量の推定近似に $\mathrm{GFR}_{\mathrm{c}} /$ $G_{F R}$ 比を用いることとした . Figs. 2，3に GFR $/ G_{C} / R_{A}$ と产の線形および二次近似式を示した .これらより，小 児薬用量の近似式は, 以下のように求められた(Eqs. (15) (18)) .

1)男児

線形近似: $D_{C} \cong D_{A} \cdot(0.054 \mathrm{Age}+0.093) \quad \cdots$ Eq. (15)

二次近似: $D_{C} \cong D_{A} \cdot\left(0.0012 \mathrm{Age}^{2}+0.035 \mathrm{Age}+0.16\right)$

‥Eq. (16)

2)女児

線形近似: $D_{C} \cong D_{A} \cdot(0.062 \mathrm{Age}+0.12) \quad \cdots$ Eq. (17)

二次近似: $D_{C} \cong D_{A} \cdot\left(0.00026 \mathrm{Age}^{2}+0.057 \mathrm{Age}+0.13\right)$

\section{3. 小児薬用量推定近似式の妥当性についての検討}

対象薬剂の添付文書小児薬用量を基準として，線形あ るいは二次近似式を用いて算出される小児薬用量および A ugsberger 式を用いて算出される小児薬用量の相対 RMSE％を Fig. 4 に示した . 相対 RMSE％は，男児では $\operatorname{VCM}($ iv.) , FOM(p.o.)，NFLX(p.o.)は 16.7(A ugsberger 式)
に対して 9.7(線形近似)と 8.0(二次近似)，乥して女児で はVCM(iv.) , FOM(p.o.) , NFLX(p.o.)は17.5に対して 14.4 と 12.8, ABK(iv.) , AMPC(p.o.)は 24.3に対して 12.8 と 14.0, FOM(iv.)は44.7に対して 38.7 と 39.5, DGX (p.o.) は 31.1 に対して 22.2 と23.3となった．したがって，男 児ではVCM(iv.)，FOM(p.o.)，NFLX(p.o.)，女児ではす べての薬㓢でA ugsberger 式より算出される小児薬用量 と比較して，近似式より算出される小児薬用量のほうが 添付文書小児薬用量に対して予測精度が高かった . ま た，近似式を用いて算出される小児薬用量と A ugsberger 式を用いて算出される小児薬用量との添付文書小児薬用 量に対する予測精度は，男児では有意差が認められな かった $(p>0.05)$ が ，女児では近似式を用いたほうが予測 精度は有意に高かった $(p<0.05)$.

各薬斉の添付文書小児薬用量と導出した近似式(Eqs. (15)〜(18))から算出された小児薬用量の間には，傾き $0.766, \mathrm{y}$ 切片 0.061 (線形近似)および傾き $0.772, \mathrm{y}$ 切片 0.058(二次近似)の相関性が見出された .一方で, Augs berger 式から算出された小肾薬用量とは，傾き $0.533, y$ 切片 0.166 の相関性であった(Fig. 5) . なお，相関解析 には，2016点(各薬剂 288x 7)を用いたが，図示するに あたって視認性を高めるため, 各薬剂において 14 点(男 児女児各 7 点)ずつ等間隔で選びプロットした . 結果と して，傾きが 1 に近い順に二次近似式 A ugsberger 式であり，しかも y 切片が $0 に$ に近い順に二次 近似式三線形近似式 < A ugsberger 式であったことから， 予測性の面でわれわれの提唱した式は A ugsberger 式よ り優れていた .

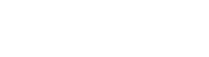

医師が小児に薬用量を処方する際，添付文書に記載さ れた体重あたりの小览薬用量を参考にして用量を設定す ることがほとんどである．しかしながら，添付文書上に 小児薬用量が記載されていない場合は, A ugsberger 式， Young 式, Clark 式 , Crawford 式, von Harnack の換算表 のように年齢，体重光して体表面積などを変数とした連 続的または離散的な関数を用いる方法が使用されてい る. 弚のなかでも体表面積に近似した A ugsberger 式や von Harnack の換算表は，簡易的に小児薬用量を算出す ることができるため，臨床現場では汎用されている．ー 方で, A ugsberger 式による薬用量推定は年齢に対して直 線的に増加するため，小児期全体の推定については不正 確な薬用量推定になる可能性が高く，von Harnack の換 算表は, 3 力月，6力月，1歳，3歳，7.5歳，12歳と不 連続な值であるため年齢や月齢によっては推定できない 場合がある．また，体重あたりで薬用量を設定する場合 の問題点として, 実際の藏器機能は同一だが, 肥満児な ど脂肪や筋肉量の違いで薬用量が異なる場合が生じる． われわれは，すでに腎排泄型薬物においては，小览薬用 


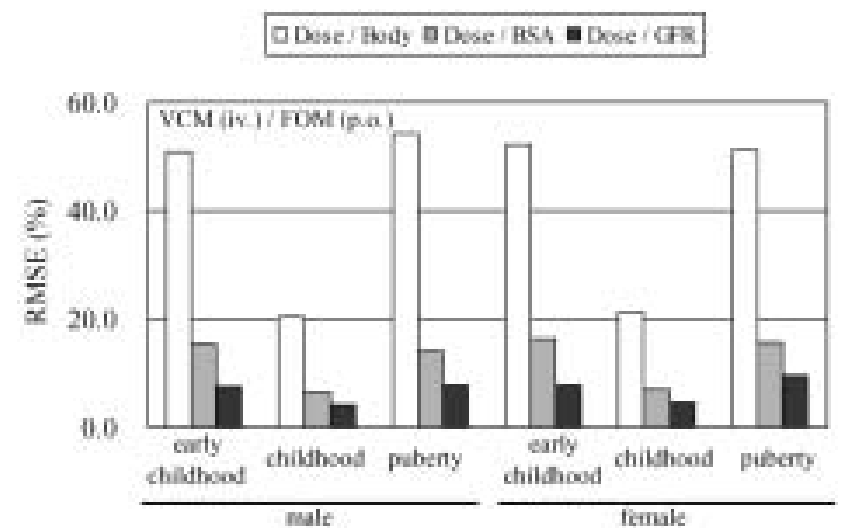

D Dose / Body a Dose / BSA a Dose / GR

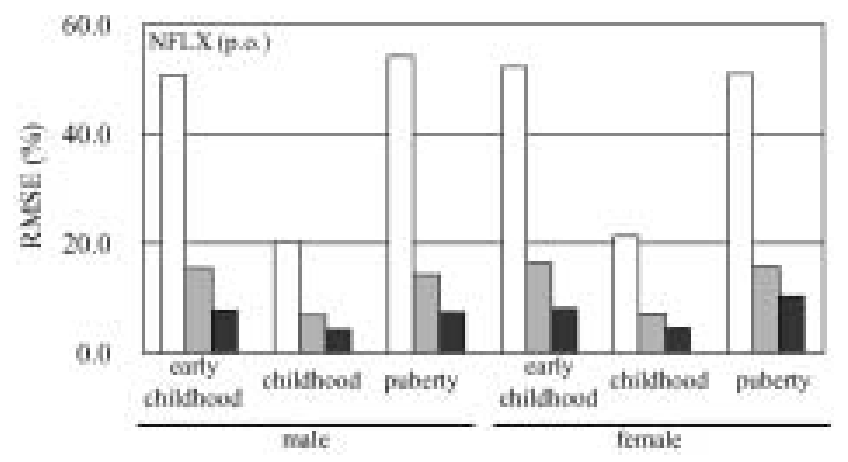

- Dose / Dody a Dose / BSA a Dowe / Ga:

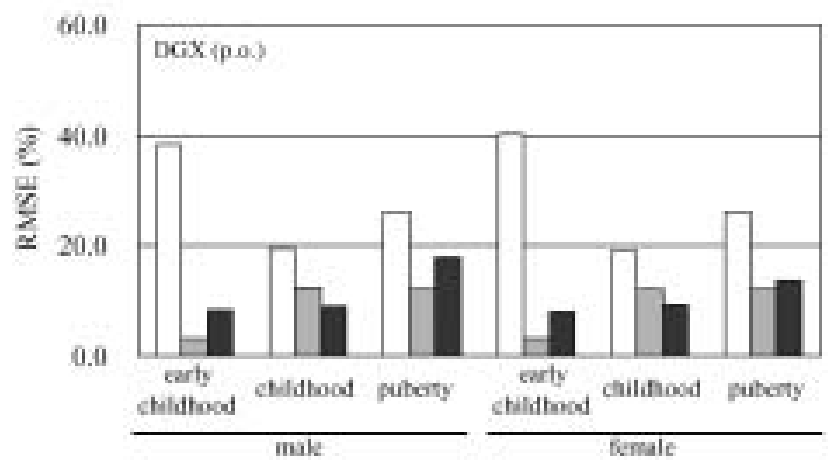

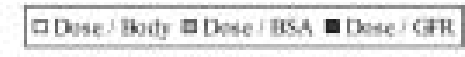
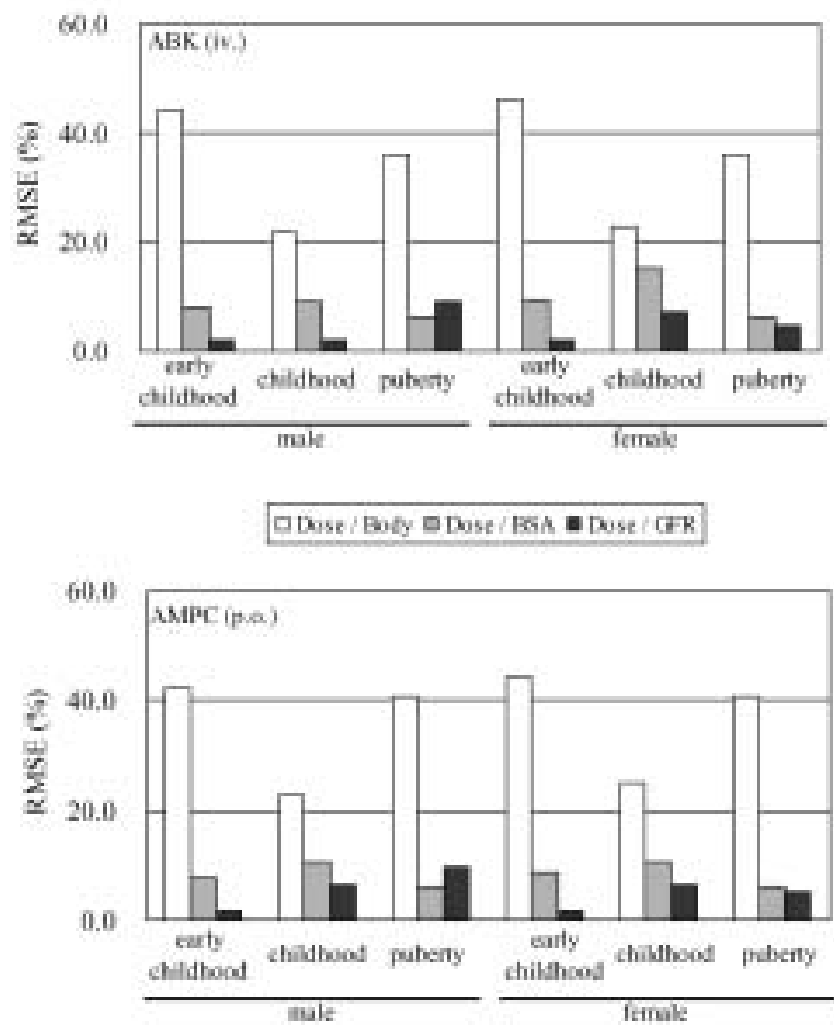

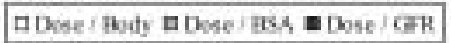

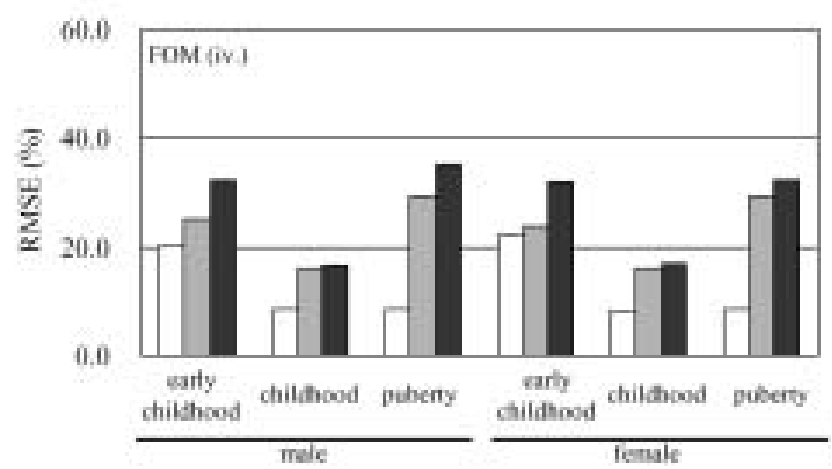

Fig 1. Relative RMSE (\%) of Doses for VCM (iv.), FOM (iv., p.o.), ABK (iv.), NFLX (р.о.), AMPC (р.о.), DGX (р.о.) Normalized by Body, BSA, and GFR.

量の推定の指標として薬物 CL と直接的に関係する GFR を用いたほうがより正確であることを示し，成長過程に 応じた成人薬用量からの新生児・乳幼児薬用量の推定に 成功した 2). 光こで本研究では, 対象年齢を 2 歳から 15 歳までに拡大し，GFR を用いた推定式から，臨床現場 においても汎用できるように年齢を用いた簡易的な近似 式を性別ごとに求め, 小児期の成長過程に応じた簡便な 推定法を提唱した。

検討薬剂を採択する際，75\%以上の腎排泄型で添付 文書に小児薬用量の記載がある薬剂は限られており，本 検討では抗生物質が中心となった . 検討薬剂の添付文書
小児薬用量を Body，BSA，GFR あたりで表現し，Dose/ Body (mg/body), Dose/BSA (mg/m²), Dose/GFR(mg • $\mathrm{min} / \mathrm{mL})$ の值を各年齢ごとに算出した結果，大半の薬剂 において，Dose/GFR の RMSE が最も小さく小児期を通 して最も一定の值を示した(Fig. 1). 一方で，FOM(iv.) のみ Dose/Body の RMSE(小児期全体の平均值に対する 男女別の各年齢群の平均值のバラツキ)が最も小さく一 定の值を示した .これは,FOM(iv.)のDose/Body が男 児・女児ともに約 6 歳で成人值を示し，学童期，思春期 の平均值が等しい值となったためである . したがって， Dose/Body が一定な条件下で各年齢群の平均值が必ず変 

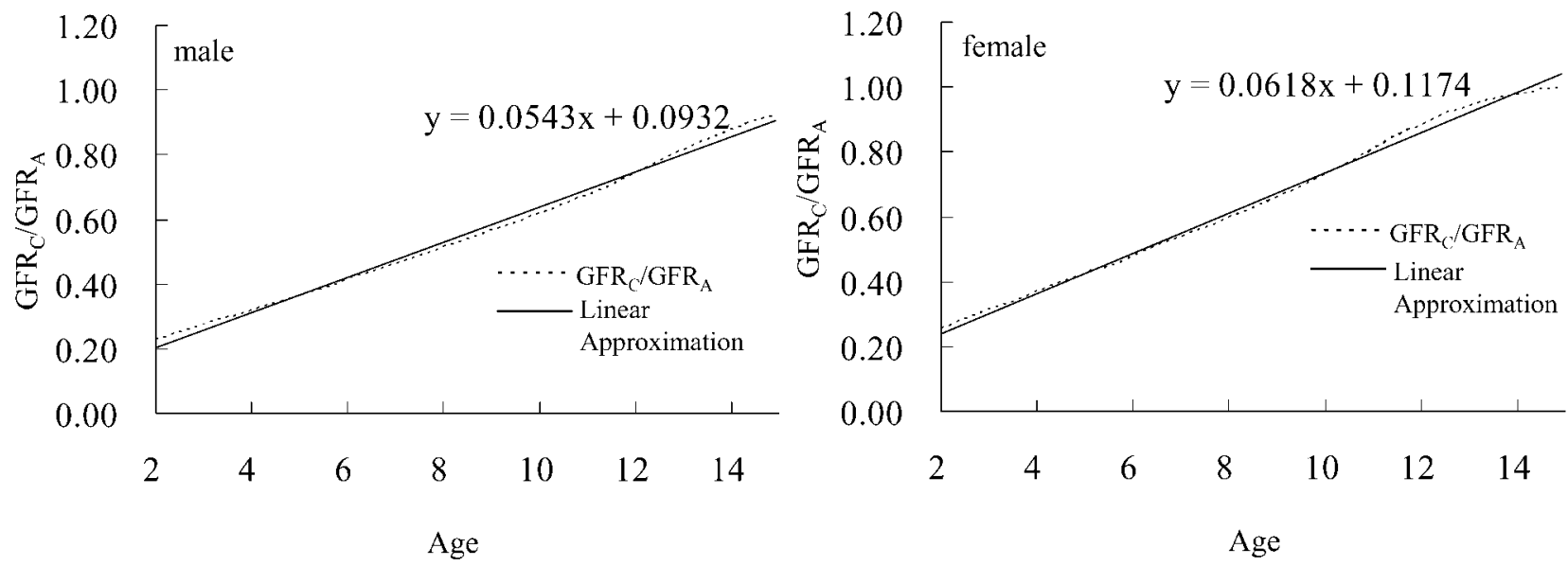

Fig 2 . A ge related Changes for $G_{F} R_{C} / G F R_{A}$ During Childhood Employed for Linear A pproximation of Pediatric Doses. GFR $/$ GFR $_{\mathrm{A}}$ was calculated using Eqs. (1) and (2) in the method section with the calculation interval of approximately 0.083 year of age.

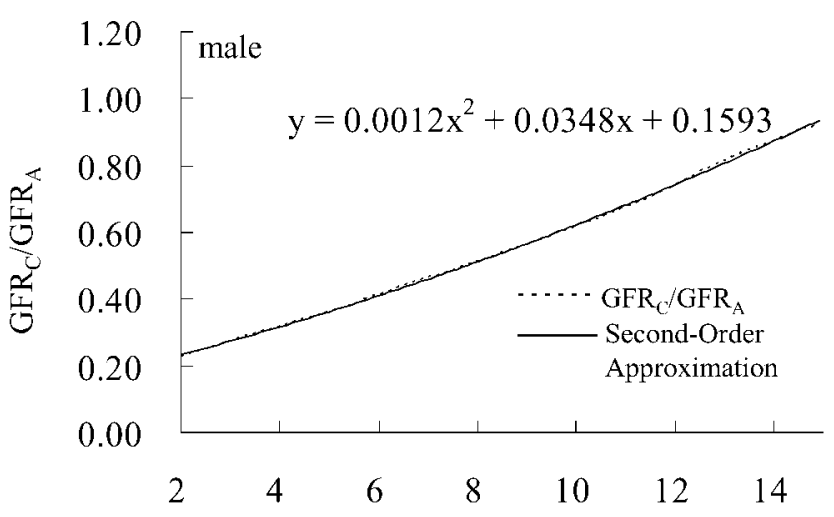

Age

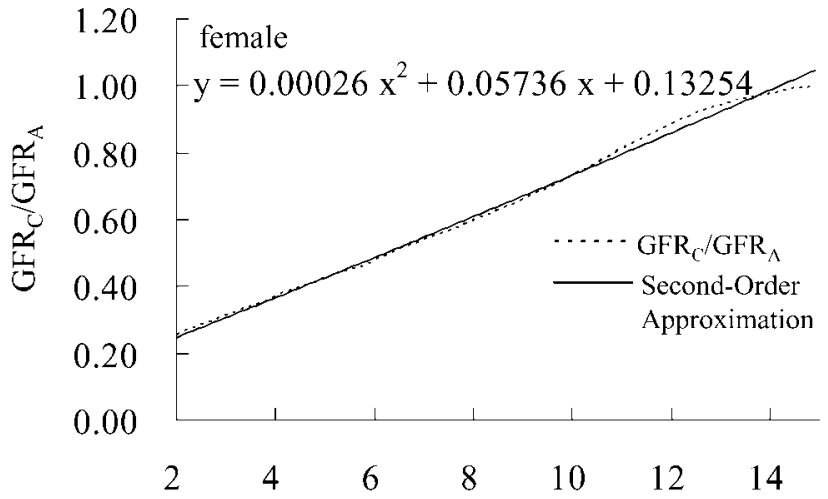

Age

Fig 3. Age related Changes for GFR $/ G_{F} R_{A}$ During Childhood Employed for Second-Order A pproximation of Pediatric Doses. GFR $/ G_{C} R_{A}$ was calculated using Eqs. (1) and (2) in the method section with the calculation interval of approximately 0.083 year of age
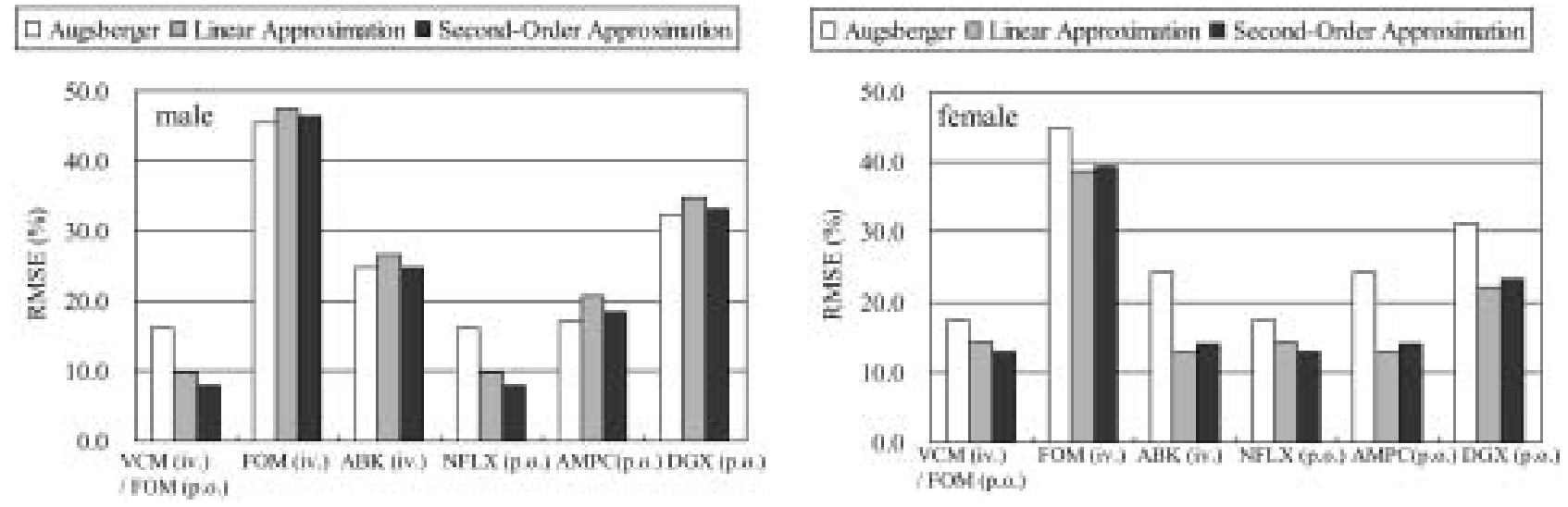

Fig 4. Relative RMSE (\%) of Doses for VCM (iv.), FOM (iv., p.o.), ABK (iv.), NFLX (р.o.), A MPC (p.o.), DGX (p.o.) in Comparison with the Pediatric Doses Described in Drug Package Inserts.

化するDose/BSA，Dose/GFRに比して，Dose/Body が 小児期全体の平均値に対して各年齢群の平均値の差が小
さい，すなわちRMSE が最も小さいという，小児の腎 機能発達とは対応しない結果となった . 

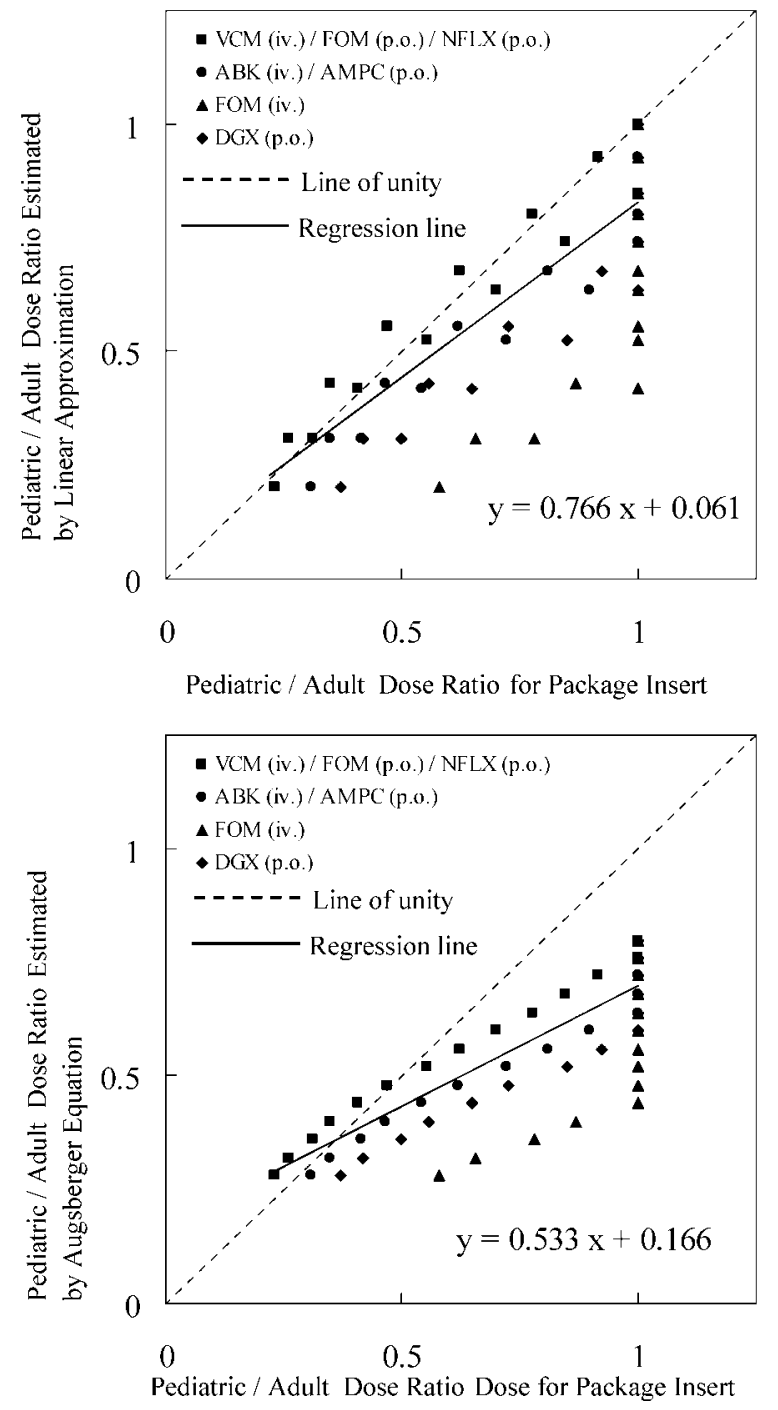

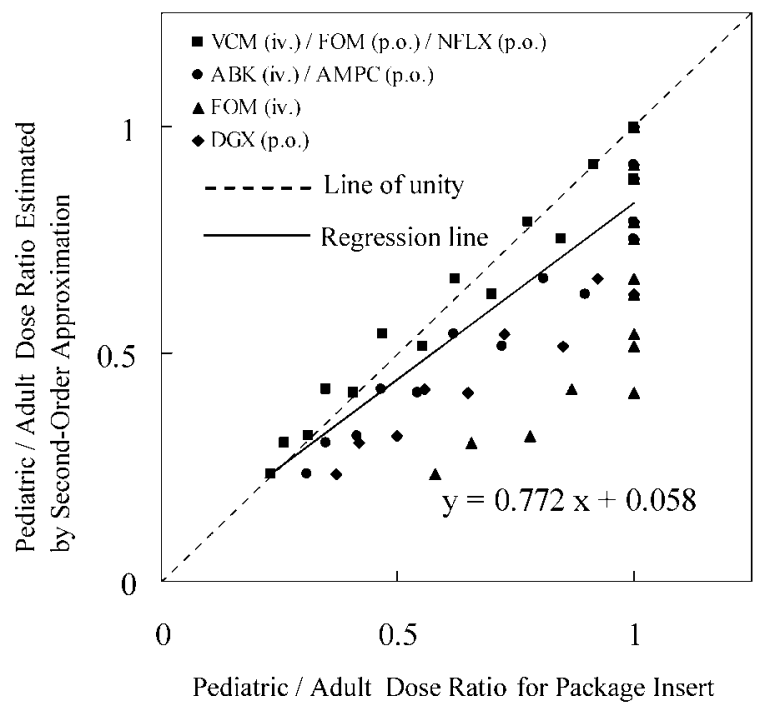

Pediatric / Adult Dose Ratio for Package Insert

Fig 5 . Relationship between Pediatric/Adult Dose Ratio for Package Insert and Pediatric/Adult Dose Ratio Estimated by Linear Approximation Method, Second-Order Approximation Method and A ugsberger Equation. The dose ratios for the two groups of drugs (VCM (iv.), FOM (р.о.), NFLX (p.o.) ; ABK (iv.), AMPC (p.o.)) are overlapping and shown as the same symbols.

小児の GFR は , 血清クレアチニン值より Schwartzの eGFR 換算式(Eq. (19) $)^{18)}$ からも推定できる .

小児の推定 $\operatorname{GFR}\left(\mathrm{mL} / \mathrm{min} / 1.73 \mathrm{~m}^{2}\right)=\frac{0.55 \times H T(\mathrm{~cm})}{\text { 血清 } C r(\mathrm{mg} / \mathrm{dL})}$

したがって，GFR を薬用量推定に用いることで小児 において腎機能が低下した場合でも対応可能であると考 えられる.以上のことから，腎排泄型薬物については， GFR を考慮した小児薬用量の推定が，臨床現場で主に 汎用されている BSA に基づく推定法よりも妥当である と考えられた .

そこで GFR $/ G F R_{A}$ を用いた小児薬用量推定式(Eq. (10))から，GFR $/ G^{\prime} F R_{A}$ に対する線形および二次近似式 を導出した。光して, 各近似式とBSA に線形近似する A ugsberger 式から算出される小児薬用量と添付文書小児
薬用量と比較することで近似式の妥当性について検討し た。乥の結果, 男児のFOM(iv.), ABK(iv.), AMPC(p.o.)，

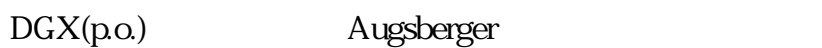
度は同等であり，女児のFOM(iv.), ABK(iv.), AMPC(p.o.)， $\operatorname{DGX}$ (p.o.)，光して男・女児のVCM(iv.), FOM(p.o.)， NFLX(p.o.)については, 予測精度は近似式のほうが優れ ていた(Fig. 4). 男・女児間の成長の差をみると，2000 年に報告された日本人小児の標準体重より女児のほうが 小児期の成長が早く，思春期の女児では15歳でほとん ど成人と同じ值となる．炎の結果，近似式も男児に比し て女児のほうがやや高用量を予測できる推定式となり， 同じ薬斉でも予測精度に差が生じたと考えられる．添付 文書には性差による用量を設定していないため，厳密に はわれわれが導出した近似式のほうがより小児の生理学 的発達を考慮した推定であり，正確な推定值を予測でき 
た可能性が示唆された。.FOM(iv.)に関しては, 添付文書 小児薬用量に対する近似式から算出される小児薬用量の RMSE(\%)が男児・女児ともに $30 \%$ 以上あり，性差に関 係なく添付文書小肾薬用量と近似式による推定値に比較 的大きな乘離があった .これは，検討に用いた添付文書 最小小児薬用量がFOM(p.o.)では $40 \mathrm{mg} / \mathrm{kg} /$ day，FOM (iv.)では $100 \mathrm{mg} / \mathrm{kg} /$ day と大きな差があり，通常の場合 (Dose(p.o.) > Dose(i.v.))とは逆であることに起因する乘離 といえる.また，FOM(iv.)の添付文書小児薬用量は, 1980 年以来末改訂であり，弚の後の臨床データの蓄積から導 出したものではないため, 今回算出した近似式の投与量 でも十分である可能性が示唆された .

6 種の腎排泄型薬物の添付文書小児薬用量と A ugsberger 式を用いた小児薬用量の線形近似式を用いた 小児薬用量との間の相関式に比して，近似式を用いた小 児薬用量との間の相関式のほうが傾きがより1に近く， y 切片がより0に近い結果となった .このことから，小 児期における变動因子としての GFR の選択および線形 および二次近似式からの小児薬用量推定は妥当であった といえる．また，厳密には二次近似式のほうが推定精度 は高いが，Fig. 4 に示したRMSE(％)値や Fig. 5 に示し た傾きおよびy 切片の差を考えると臨床現場では煩雑で はない線形近似式のほうが有用であると考えられた .

本研究では, 腎排泄型薬物の小児薬用量の推定法とし て薬物動態学的变動因子である GFR を指標とし, 他の 変動因子である BSA より有意に良好な結果を得た。弚 して，臨床現場で汎用できるよう性差も考慮した線形近 似式を導出したことは有用であると考えられる．今回わ れわれは，最終的に腎排泄型薬物の小览薬用量を累乗計 算する必要なく四則演算のみで鳬速に算出できる簡便推 定法を提唱した . 肝代謝型薬物については現在, 肝体積 を考慮した同樣な方法を開発中である(論文作成中)，従 来の小児薬用量の推定法である A ugsberger 式 ,Y oung 式 , Clark 式, Crawford式, von Harnack の換算表などは, 薬物の代謝排泄過程と光の生理学的变動を考慮しておら ず, 本研究のように薬物動態学的メカニズムに立脚して 求められた小児薬用量推定法の普及が期待される .

謝辞 本研究は, 「昭和大学ハイテクリサーチ研究」による ものである

\section{引用文献}

1) 鈴木信也, 関山正夫 , 杉山恵理花, 佐藤均, 医師 ·看護 師・薬剂師間の情報共有を目的とする院内 LAN を用い た医薬品情報データベースの構築，医療薬学，34, 11271136 (2008).
2) 鈴木信也, 村山悠佳, 杉山恵理花, 関山正夫, 佐藤均, 腎機能の生理学的発達を考慮した腎排泄型薬剂における 新生児・乳幼児薬用量の推定, 薬学雑誌, 129，829-842 (2009).

3) “塩酸バンコマイシン点滴静注用 $0.5 \mathrm{~g}$, 塩酸バンコマイ シン点滴静注用キット $0.5 \mathrm{~g}$ 添付文書”, 塩野義製薬株式 会社, 2008 年 4 月改訂版.

4)“ホスミシン踶 250 , 錠 500 添付文書”, 明治製菓株式会 社, 2008年 1月改訂版.

5) “ ホスミシン ${ }^{\circledR} S$ バッグ $1 \mathrm{~g}$ 点滴静注用 , バッグ $2 \mathrm{~g}$ 点滴 静注用添付文書”，明治製菓株式会社，2007 年 4 月改訂 版.

6) K. Murakawa, T. Murakawa, H. Sakamoto, S. Fukada, T. Konishi, M. Nishida, Pharmacokinetics of fosmidomycin, a new phosphonic acid antibiotic, Antimicrob. Agents. Chemother., 21 , 224-230 (1982).

7) “ ハベカシン ${ }^{\circledR}$ 注射液 $25 \mathrm{mg}, 75 \mathrm{mg}, 100 \mathrm{mg}, 200 \mathrm{mg}$ 添 付文書”, 明治製菓株式会社, 2008 年 6 月改訂版.

8) K. Totsuka, K. Shimizu, N. Mitomi, T. Niizato, M. A raake, Evaluation of once daily administration of arbekacin. Experimental study and determination of pharmacokinetic properties in man, Jpn. J. Antibiotics., 47 , 676-692 (1994).

9) “小児用バクシダール ${ }^{\circledR}$ 錠 $50 \mathrm{mg}$ 添付文書” , 杏林製薬株 式会社, 2007 年 10 月改訂版.

10)“バクシダール ${ }^{\circledR}$ 錠 $100 \mathrm{mg}$, 錠 $200 \mathrm{mg}$ 添付文書” , 杏林 製薬株式会社, 2007 年 2 月改訂版 .

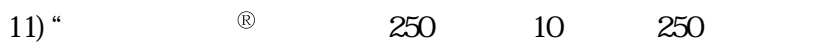
書”,アステラス製薬株式会社，2008年 8 月改訂版 .

12) L.S. Goodman, A. Gilman “"グッドマン・ギルマン薬理 書下”, 第 9版, 高折修二, 福田英臣, 藤原元始, 大森 義仁, 高木敬次郎, 上條一也監訳, 廣川書店, $1999, \mathrm{pp}$. 2245-2343.

13) “ジゴシン踶 $0.125 \mathrm{mg}$, 錠 $0.25 \mathrm{mg}$, 散 $0.1 \%$ 添付文書” , 中外製薬株式会社, 2005 年 11 月改訂版.

14) W.A. Ritschel “’グラフによる臨床薬物動態解析法”, 海 老原昭夫，鈴木けい子訳，薬事日報社，1998, pp. 155-162.

15) T.N. Johnson, A. Rostami-Hodjegan, G.T. Tucker, Prediction of the Clearance of Eleven Drugs and A ssociated V ariability in Neonates, Infants and Children, Clin. Phamacokinet., 45 , 931-956 (2006).

16) M.E. Burton, L.M. Shaw, J.J. Schentag, W.E. Evans "“ Applied Pharmacokinetics \& Pharmacodynamics," Lippincott Williams \& Wilkins., Philadelphia, 2006 , pp. 213-230.

17) L.B. Sheiner, S.L. Beal, Some Suggestions for Measuring Predictive Performance, J. Pharmacokinet Biopharm., 9, 503-512 (1981).

18）松尾清一, 飯野靖彦, 内田俊也, 井関邦敏, 今井圓裕, 木村健二郎, 塚本雄介, 新田孝作, 原茂子, 松尾清一, 松山健, 守山敏樹, 山縣邦弘, 渡辺毅, 安田宣成, “CKD 診療ガイド”, 日本腎藏学会編, 東京医学社, 2007 , pp. 40-41. 